\title{
Konsep Ekonomi Pada Masa Rasulullah Nabi Muhammad SAW
}

\section{Anisa Lusiana}

Pemikiran ekonomi Islam muncul bersamaan dengan diturunkannya Al-Qur'an dan masa kehidupan Rasulullah pada akhir abad 6 M hingga awal abad 7 M. Pelaksanaan sistem ekonomi Islam telah ada dan dilaksanakan oleh Rasulullah SAW sebagai seorang Rasul tauladan bagi umat muslim. Bahkan bangsa Arab telah terkenal sebagai bangsa pedagang sebelum periode Rasulullah Saw. ${ }^{1}$ Dalam sejarah tercatat, bahwa Mekkah merupakan urat nadi dari pusat perekonomian di sana atau dikenal dengan sebutan Ummul Qurā. Pada masa Rasulullah, saudagar kaya sangat menentukan pertumbuhan perekonomian. Hal ini disebabkan oleh pembangunan baik sektor keagamaan, spritual maupun kebudayaan dibangun dengan mengutamakan prinsip bisnks, keuntungan dan jual beli. Sehingga dari hal tersebut menyebabkan ketidak adilan dan ketimpangan ekonomi, karena para pedagang hanya fokus pada meraup keuntungan sebanyak-banyaknya. Hingga yang miskin semakin miskin dan yang kaya semakin kaya.

Hijrah Rasulullah dari Mekkah ke Madinah adalah sebagai batu loncatan untuk membangun masyarakat yang baru dinegeri yang aman, karena melihat kondisi di Mekkah saat itu sudah tidak baik-baik saja. Oleh karena itupula Rasulullah yang merupakan pemimpin dari kaum muslimin mengerahkan kepada seluruh umat muslim untuk hijrah ke Madinah terkecuali bagi mereka yang memiliki halangan. Untuk Intensifikasi pembangunan, Rasulullah pertama kali membangun masjid sebagai lokomotif pembangunan. Masjid menjadi pusat segala aktivitas yang berbasis etis dan moralitas bagi masyarakat. Selain itu masjid juga menjadi tempat dalam menyusun aturan dan kebijakan-kebijakan untuk menerapkan prinsip sosial dan kemanusiaan. Adapun karakteristik perekonomian pada masa Rasulullah adalah sosial-religius yang menekankan kerja kooperatif bagi kaum Muhajirin dan Anshar yang menyebabkan meningkatnya distribusi pendapatan dan kesejahteraan masyarakat. ${ }^{2}$

Salah Satu Sebab terjadinya peredaran uang yang terlalu tinggi adalah terjadinya defisit anggaran yang ditutup dengan pinjaman. Karena itu agar kebijakan moneter menjadi lebih efektif,

\footnotetext{
${ }^{1}$ Ibnudin, Pemikiran Ekonomi Islam Pada Masa Rasulullah, Jurnal Pendidikan dan Studi ekonomi Islam Vol. 5 No. 1 , 2019, hal. 51-61.

${ }^{2}$ Ayief Faturrahman, Fondasi etis ekonomi Pada Masa Rasulullah, Jurnal Ekonomi Syariah Vol. 3 No. 2 september 2018, hal.56-73
} 
perlu kordinasi antara kebijakan moneter dan fiskal untuk mewujutkan tujuan-tujuan nasional. Pada awal pemerintahan Islam dimasa Rasulullah jarang terjadi defisit dan Baitul Mall merupakan lembaga yang diberikan wewenang dalam mengatur pengelolalaan moneter. Rasulullah memperkenalkan konsep baru di bidang keuangan negara pada abad ketujuh, yakni semua hasil pengumpulan negara harus dikumpulkan terlebih dahulu dan kemudian dibelanjakan sesuai dengan kebutuhan negara. ${ }^{3}$

Didalam pengelolaan moneter awal Pemerintah Islam mengalokasikan dana untuk pemyebaran Islam, pendidikan dan kebudayaan, pengembangan ilmu pengetahuan, pengembangan inprastruktur, dan penyediaan layanan kesejahteraan sosial. Seluruh alokasi dana baitul mall tersebut mempunyai dampak terhadap pertumbuhan ekonomi baik secara langsung atau tidak, seperti alokasi untuk penyebaran Islam yang berdampak terhadap kenaikan Agregate Demaand sekaligus Agregate Supply karena populasi akan meningkat dan penggunaan sumberdaya alam semakin maksimal. ${ }^{4}$

Selain itu pada masa Rasulullah juga diberlakukan kebijakan Fiskal. Pada jaman Rasulullah Saw, sisi penerimaan APBN terdiri atas pajak tanah (Kharaj) zakat, khums (pajak 1/5), jizya (sejenis pajak atas badan orang non muslim), dan penerimaan lain-lain (kaffarah/denda). Pengeluara terdiri dari untuk kepentingan pendidikan dan kebudayaan, dakwah, Ilmu Pengetahuan dan Teknologi, kesejahteraan sosial, Hankam dan belanja pegawai. Secara ekonomi makro, hal ini akan menciptakan built-in stability. Ia akan menstabilkan harga dan menekan inflasi ketika permintaan agregat lebih besar daripada penawaran agregat. Dari sisi penerimaan yaitu Zakat. Zakat dalam alqur'an telah diatur bahwa terdapat golongan yang berhak menerima zakat. ${ }^{5}$ Dana Zakat, Infaq, sedekah dan Khums mempunyai dampak yang sangat besar dalam perekonomian yaitu banyaknya masyarakat yang sebelumnya berstatus hamba sahaya atau orang lemah berubah jadi mandiri dan merdeka. ${ }^{6}$

\footnotetext{
${ }^{3}$ Agus Marimin, Baitul Maal Sebagai Lembaga Keuangan Islam Dalam Memperlancar Aktivitas Perekonomian, Jurnal Akuntansi dan Pajak, Vol.14, No. 02, 2014, hal 39-42.

${ }^{4}$ Hoirul Amri, Kebijakan Moneter Pada Awal Pemerintahan Islam Dalam Pembangunan Perekonomian (Studi Empiris Pasa Masa Rasulullah SAW dan Sahabat), Muqtashid, Vol.1, No. 01, Maret 2016, hal. 9-24.

${ }^{5}$ Inggritia Safitri dan Nurul Huda, Islamic Social Finance Optimalization For Economic Growth (Covid 19 In Indonesia), LAA MAISYIR, Vol.8 No. 1, 2021, hal. 1-12.

${ }^{6}$ Naimah, Konsep Hukum Zakat Sebagai Instrumen Dalam Meningkatkan Perekonomian Ummat, Syariah Jurnal Hukum Dan Pemikiran, Vol.14, No. 1, 2014.
} 


\section{DAFTAR PUSTAKA}

Indonesia, Universitas. “Http://Journal.Uin-Alauddin.Ac.Id/Index.Php/Lamaisyir Publisher: Fakultas Ekonomi Dan Bisnis Islam UIN Alauddin Makassar,”2021, 1-12.

NAIMAH, NAIMAH. "Konsep Hukum Zakat Sebagai Instrumen Dalam Meningkatkan Perekonomian Ummat." Syariah Jurnal Hukum Dan Pemikiran 14, no. 1 (2014). https://doi.org/10.18592/syariah.v14i1.66.

"No Title" I, no. 01 (n.d.): 9-24.

Pada, Studi, and Masyarakat Perantau. “ACTIVA : Jurnal Ekonomi Syariah” 1, no. April (2018): $56-73$.

Perekonomian, Memperlancar Aktivitas. "BAITUL MAAL SEBAGAI LEMBAGA KEUANGAN ISLAM DALAM MEMPERLANCAR AKTIVITAS PEREKONOMIAN Agus Marimin" 14, no. 02 (2014): 39-42.

Thingking, T H E, O F Islamic, Economy In, and Muhammad Prophet. "PEMIKIRAN EKONOMI ISLAM PADA MASA NABI" 5, no. 1 (2019): 51-61

Safitri, Inggritia dan Nurul Huda. 2021. Islamic Social Finance Optimalization For Economic Growth (Covid 19 In Indonesia), LAA MAISYIR, Vol.8 No. 1, hal.1-12. 